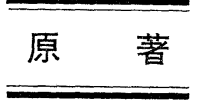

\title{
喀痰集細胞法（郵送-Dithiothreitol 法）の開発
}

\author{
大阪府医師会臨床検査センター細胞診断科1), 大阪府立成人病センター内科2) \\ 矢羽田一信 ${ }^{1)}$ 伏見 恵 ${ }^{1)}$ 川井一男1 \\ 赤土 洋三1 ${ }^{1}$ 宝来 威
}

\begin{abstract}
粘液融解剂 Dithiothreitol（DTT) を用いた喀痰保存液（0.005\% DTT, 35\% エタノールなどを 含む) を開発調整した (DTT 液)。また, 沈渣が取りやすく, 郵便ポストに投函可能な粘液粉砕翼 付喀痰容器を開発した. DTT 液とこの容器を用いた喀痰集細胞法 (DTT 集細胞法) では喀痰中の 粘液の融解率は 72 時間で $96 \%$ であった. 本法で作成した細胞診標本は粘液が融解されているので, 背景には粘液片はなく, 細胞は標本上に均等に分布したが, 細胞集団の保存性は良かった. 癌細胞 の細胞質・核の染色性も良好で従来の肺癌細胞の判定基準に従って細胞型の判定も可能であった. 同一喀痰を用いた DTT 集細胞法と直接塗抹法の陽性率の比較では, 肺癌症例の喀痰 100 件での癌 細胞検出率注 DTT 集細胞法は $65 \%$, 直接塗抹法 $43 \%$ で, DTT 集細胞法が $22 \%$ 高率であった. また細胞型別では, DTT 集細胞法では扁平上皮癌 $68 \%$, 腺癌 $61 \%$ で直接塗抹法の扁平上皮癌 $48 \%$, 腺癌 $34 \%$ を大きく上回った. DTT 集細胞法は標本作成操作が簡易で同時に多数の検体の処理がで きるので, 集団検診をはじめ増加する喀痰細胞診に有用な方法である.
\end{abstract}

Key words : Lung cancer-Sputum cytology-Cell concentration-Dithiothreitol

\section{I. 緒言}

集細胞法による喀痰細胞診は喀痰中の細胞成分をでき るだけ多く集め癌細胞検出率を向上せしめようというも のである．また，液状検体として取り扱うことから喀疢 の保存が可能である.すでに集細胞法としては, 物理的 に喀痰粘液を粉砕する Saccomanno 法3,5), 化学的に喀 痰粘液を融解する蛋白分解酵素法 4 , 7), アセチルシステイ ン法1,2)などが報告されている。

The cell concentration method using Dithiothreitol for sputum cytology

Kazunobu YAHATA, C.T., I.A.C., Megumu FUSHIMI, C.

T., M.I.A.C., Kazuo KAWAI, M.D., M.I.A.C., Yozo SHAKUDO,

M.D.

Osaka Medical Association Clinical Laboratory Center

Takeshi HORAI, M.D.

Department of Internal Medicine, The Center for Adult Diseases, Osaka

論文別刷請求先 函543 大阪市天王寺区清水谷町 19 の 17 大

阪隹医師会臨床検查センター細胞晾 矢羽田一信

昭和 61 年 8 月 28 日受付

昭和 62 年 1 月 16 日受理
著者らは粘液融解性の強い Dithiothreitol (以下 DTT と略す) を用いた喀痰保存液 (以下 DTT 液) を開発し た. DTT 液で喀痰を保存すると，1〜3 日で粘液が融解 され，遠沈のみにより細胞成分を回収できるので標本作 成過程が簡易となった。 そして, 同時に開発した喀痰容 器を用いることにより，一度に多検体の処理が可能とな り，しかも検体間の混大の危険性がなくなった。 また DTT 液と本容器を用いた集細胞法 (以下 DTT 集細胞 法)の染色標本は, 細胞の保存性が良く細胞質, 核など の染色性も良好であった。

本稿では, その方法を述べ, DTT 集細胞法によって得 られた細胞所見, および癌細胞検出率について報告する。

\section{II. 方 法}

\section{1. 喀痰保存液および容器の開発}

DTT \{DL-threo-1,4 dimercapto-2,3 butandiol また は threo-2,3 dihydroxy-1,4 dithiolbutan $\left(\mathrm{C}_{4} \mathrm{H}_{10} \mathrm{O}_{2} \mathrm{~S}_{2}\right)$ \} は, 蛋白質のジスルフィド（S-S）の結合の還元剤であ る SH 化合物で, 粘液に対する作用機序は図 1 のごとく 


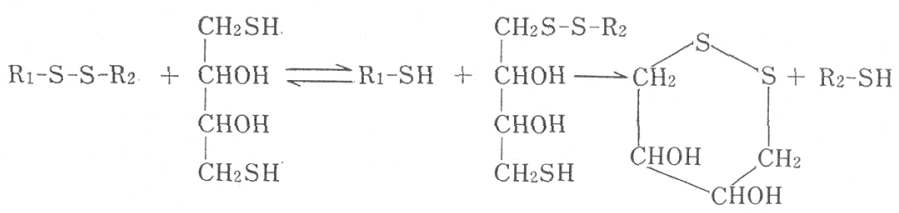

図 1 DTT の粘液に対する作用機序

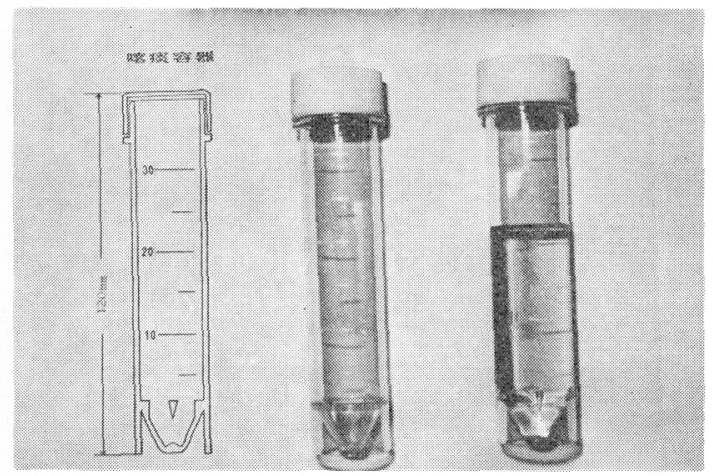

写真 1 喀疢容器

DTT 分子の両端の 2 個の SH 基がムコタンパクのジス ルフィド (S-S) 基に反応し、これを開裂させるので急速 に粘液の粘稠度が低下寸る。この DTT の粘液融解作用 を応用し, 喀痰回収中に粘液を融解させるための喀痰保 存液 (DTT 液) の調整を行った.

DTT 液の調整にあたっては, 第一に細胞の保存性, 染 色性を考慮し，第二に粘液の融解性，第三に保存液の安 定性を考慮した。エタノール濃度を 0 95\%まで $5 \%$ 段 階で濃度を変え，また DTT 濃度も $0.001 \sim 0.1 \%$ ま 変え, それぞれについて細胞の保存性, 粘液の融解性に ついて検討した結果，35\%エタノール・2\% ポリエチレ ングリコールに $0.005 \%$ の割合で DTTを加えたものが 最も上記の条件を満足したので，さらに0.0075\%の抗 結核剤 Rifampicin（以後 RFP と略す）を加えたものを DTT 液とした。

DTT 液を用い, 喀疢回収から塗抹標本作成までを同 一容器で行える喀痰容器を開発した. 攪汼力向上のため

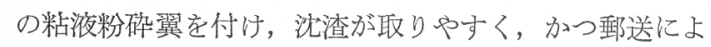
る喀痰回収を行うため郵便ポス卜に投函可能な, 最外径 $3 \mathrm{~cm}$, 高さ $12 \mathrm{~cm}$, 全容量約 $40 \mathrm{ml}$ の円筒型の容器であ 万(写真 1 ).

DTT 液とこの容器を用いた集団検診における標本作 成法は次のごとくである.

(1) DTT 液 $20 \mathrm{~m} l$ 大りの喀痰容器に 3 日間蓄疢させ, 採痰ごとに, よく混和させる。 このとき痰量は最高 10 $\mathrm{m} l$ までとする。蓄痰した容器は郵送により回収した。
(2) 回収した检体は 64 検体用の容器立てに立て, 旋 回振盪式の攪拌機(今回使用した機種は大洋科学工業の バィアルミキサー, VIX-100) で喀痰容器のまま 64 検体 同時に $2,000 \mathrm{rpm}$ で 3 分間攪挥した. 検体数が少ないと きは，サーモミキサーなどで攪挥しても良い。

(3) 攪掉後, 1,500 rpm で 3〜 5 分間遠心分離し, 上清 を少量残しぎみにして捨て, 沈渣をすり合わせ法にて塗 抹し，ドライヤーなどで 10～20 分閒乾燥後，パパニコロ ウ染色をした。本法では上清を捨てるとき初めて蓋をあ けるため, 検体間の混入の危険性がない。

\section{DTT 液による喀痰粘液の融解性の検討}

外来患者 50 名の喀出痰を用いて, DTT 液の調整後の 保存期間と喀疢の融解に要する洔間についての検討を行 った.このとき, 粘液が完全に融解され上清と細胞成分 が分離したものを融解されたものとし, 一部にでも不溶 な部分を認めたものは不溶とした。

個々の痰を駒込ピペットを用いて約 $2 \mathrm{ml}$ ずつ 4 等分 したものに, 調整直後の DTT 液, 調整後 3,6 , および 12 力月間室温で保存した 4 種類の DTT 液 $6 \mathrm{ml}$ を入れ 振盪混和した。 そして，経時的にそれぞれについて 24 ， 48, 72 時間後に喀康粘液が融解しているか否かについて 検討した。

\section{DTT 液での細胞所見亡肺癌陽性率の検討}

肺癌症例 50 例 100 件の喀痰走用いて, 直接塗抹 標本 を 2 枚作り, 残りの喀痰をDTT 液にて 3 日間保存し粘 液を融解したのち, すり合わせ塗抹標本を 2 枚作成し, 両者の細胞所見, 肺癌細胞検出率を比較検討した.

そして, DTT 液にて粘液融解処理をし標本を作成し た残りの喀痰に再度 DTT 液を大れ, 室温で DTT 液中 に 1 週間, 1，3，12 カ月間放置し，作成した標本の染色性 および細胞所見について検討した.

また $56^{\circ} \mathrm{C}$ の恒温槽に 24 時間放置し, 温度による細胞 所見の変化についても同時に検討した.

また別の肺癌症例 50 例の喀痰を $50 \%$ エタノールに 3 日間蓄痰し, その喀痰を 2 等分し, 一方を Saccomanno のブレンダーで処理し，一方をDTT 集細胞法を行い， 両者の癌細胞検出率についても検討した。 
表 1 DTT 液調整後の期間と喀疢粘液の融解率

\begin{tabular}{c|c|c|c}
\hline \hline & 24 時間 & 48 時間 & 72 時間 \\
\hline 調製直後 & $30(60.0 \%)$ & $41(82.0 \%)$ & $48(96.0 \%)$ \\
\hline 3 力月後 & $31(62.0 \%)$ & $40(80.0 \%)$ & $47(94.0 \%)$ \\
\hline 6 力月後 & $30(60.0 \%)$ & $40(80.0 \%)$ & $47(94.0 \%)$ \\
\hline 12 力後 & $28(56.0 \%)$ & $39(78.0 \%)$ & $46(92.0 \%)$ \\
\hline
\end{tabular}

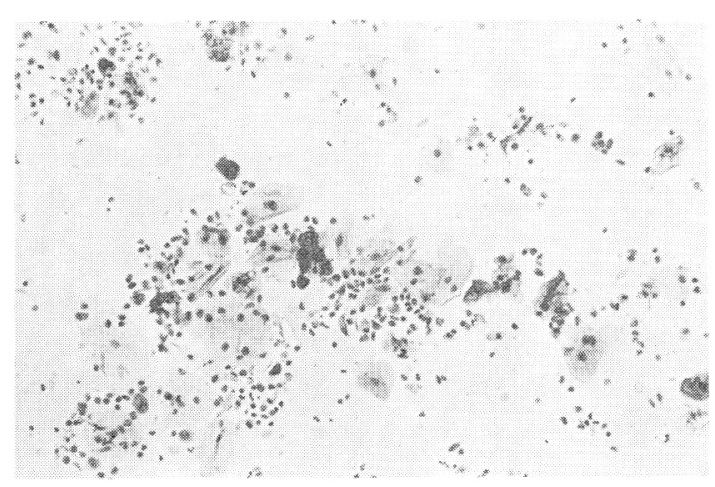

写真 2 細胞の分散 $(\times 100)$

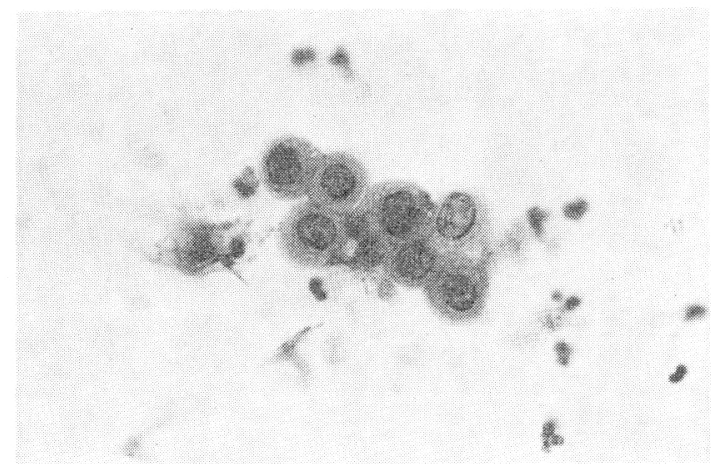

写真 3 扁平上皮化生細胞 $(\times 400)$

\section{III. 結果}

\section{DTT 液による喀痰粘液の融解性の検討}

DTT 液の安定性をみるた好にDTT 液調整後の保存 期間と粘液の融解率について検討した（表 1). 調整直後 のもの, 調整後 $3,6,12$ カ月のいずれの DTT 液も喀㾌 と混入後, 時間の経過とともに粘液の融解率は向上し 72 時閒後には, $92 \%$ 以上の融解率を示した。をた難溶性で あった検体も，遠沈後上清を捨て新しい液を大れ，攪汼 することによりすべて融解させることができた。

DTT 液に加えた抗結核剂 RFP の効力について検討 した。 ヒ下型結核菌 SGA 株, IKE 株, KAS 株を用い, それぞれ $10^{3}$ 個 $/ \mathrm{m} l$ の培養菌 $1 \mathrm{~m} l$ と非結核患者の疾 5

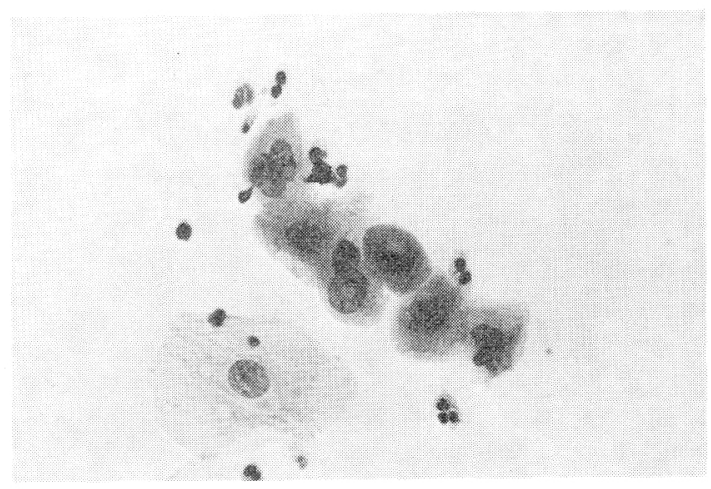

写真 4 扁平上皮化生細胞 $(\times 400)$

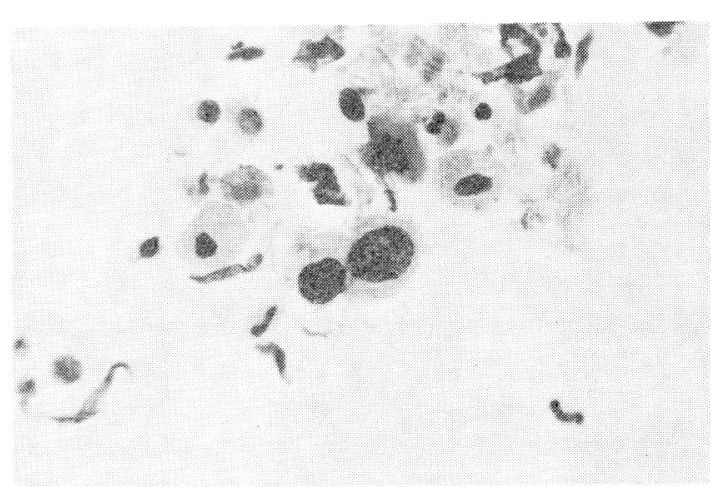

写真 5 扁平上皮癌細胞 $(\times 400)$

$\mathrm{m} l$ に揢痰保存液 $20 \mathrm{~m} l$ 定加え, 室温で 3 日間放置後遠 沈し，その沈渣を小川培地で 8 週間培養したが，培養結 果はす心゙て陰性で亦った。

\section{DTT 集細胞法における肺癌細胞の所見}

(a) 背景已分散

DTT 集細胞法では粘液が完全に融解されるため, 標 本上には粘液片がなく, 細胞の分散性は良好で, 細胞は 標本上に一層で均等に分布した (写真 2). 扁平上皮細胞, 円柱上皮細胞, 杯細胞, その他の非癌細胞は, 細胞質の 保存性がよく, 沶の㧍のの細胞の特徴が良く保存された。 扁平上皮化生細胞は単個岕るいはシート状の集団として 出現し，細胞質はライトグリーンあるいはオレンジGに 染色され, クロマチンパターンも明膫に観察された（写 真 3,4$)$.

\section{(b) 扁平上皮癌細胞}

扁平上皮癌細胞は, 孤立散在性また沙团で出現す ることが多く(写真 5), 細胞質の染色性は, オレンジ G, または,ライトグリーンに好染し，㸖は不整形で N/C は 大きく，増量したクロマチンが観察された（写真 6).

また細胞壊死物質も小集塊として認められた。 


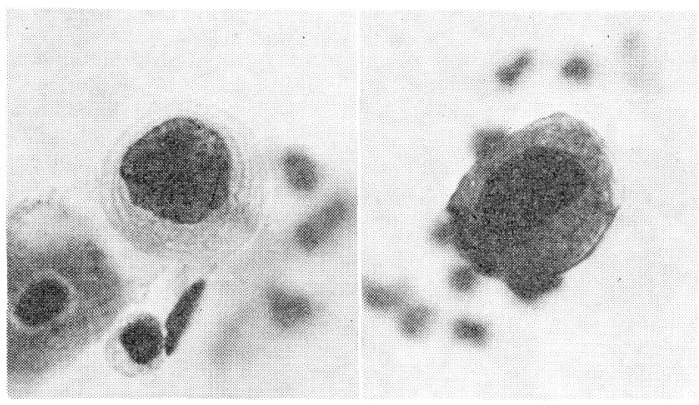

写真 6 扁平上皮癌細胞 $(\times 1,000)$

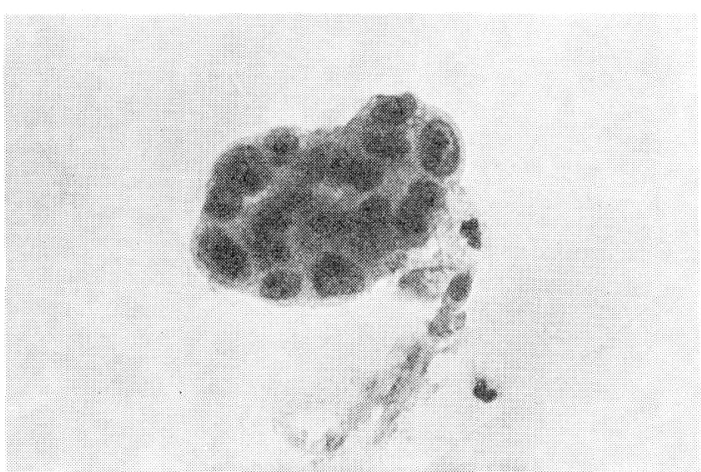

写真 7 腺澏細胞 $(\times 400)$

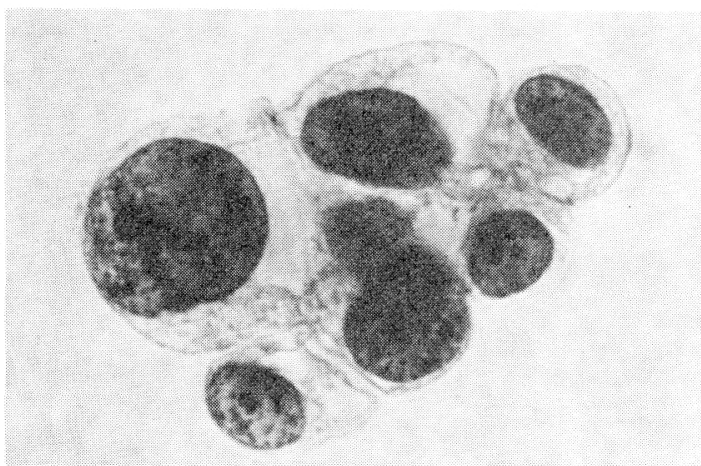

写真 8 腺癌細胞 $(\times 1,000)$

(c) 腺癌細胞

腺癌細胞は, 重積性を示す細胞集塊あるい䋲個で出 現し, ときに腺様配列も認めた (写真 7). 細胞質はライ トグリーンで染色され，泡洙状時には重厚に染まった。

核縁法薄く, 核形は不整形で, クロマチンは細顆粒状で 不均等に分布した (写真 8 ). DTT 集細胞法では, 直接 塗抹法に比し核小体は著明であった。

（d）小細胞癌細胞

小細胞癌細胞は, DTT 集細胞法では結合蹯な集団ま たは球状集塊として出現した (写真 9)。細胞は互いに押

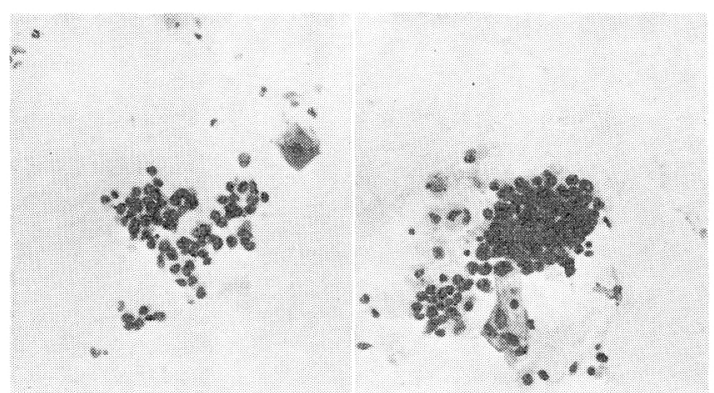

写真 9 小細胞澏細胞 $(\times 200)$

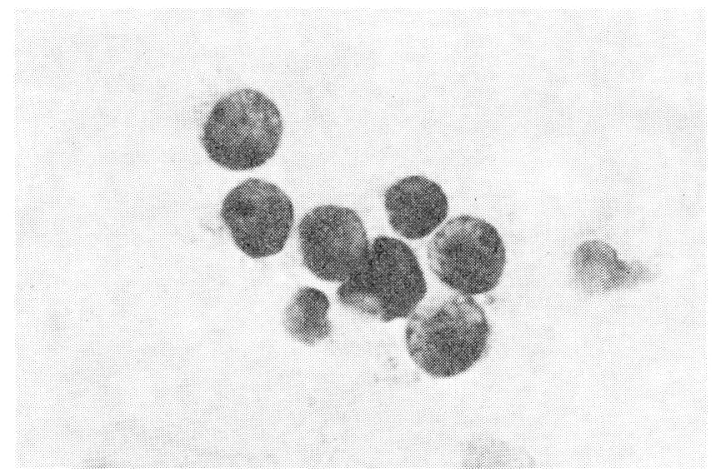

写真 10 小細胞癌細胞 $(\times 1,000)$

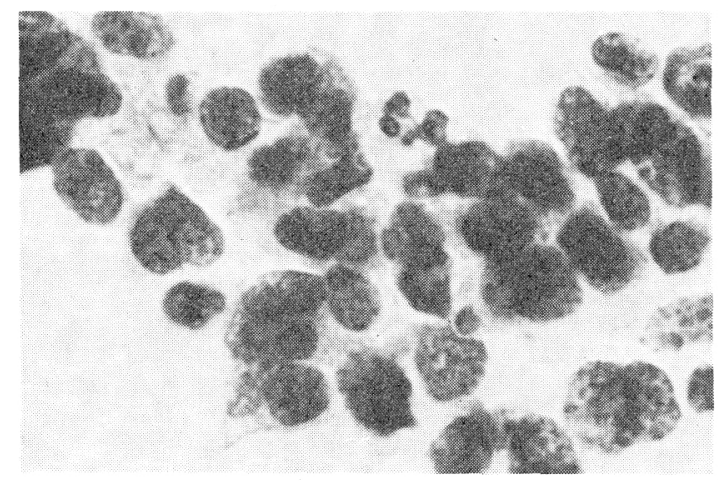

写真 11 小細胞癌細胞 $(\times 1,000)$

し合うようにして位置し，核の大小不同，核形不整が丸 られ，クロマチンは沮染状のものあるいは細顆粒状のも のがみられ，椟縁は薄く，核小体は小さく数個認められ た(写真 10). DTT 集細胞法では, 細胞質恃直接塗抹法 に比し保存される傾向にあった (写真 11)。

また，DTT 集細胞法を行い標本を作成した残りの喀 疢考再度 DTT 液で保存し， 1 週間， 1，3，12 力月間室温 で放置したのち作成した標本では, 12 力月間放置後の腺 癌細胞の細胞質に空胞化が目立ってきた点を除けば大き な変化は認められず, 細胞の保存状態は良好であった。 
$56^{\circ} \mathrm{C}$ に 24 時間放置した検体についても細胞の染色性に は変化は認为られなかった。

本法により処理した喀痰標本に PAS 染色, アルシャ ン青染色, CEA (酵素抗体法) 染色を行った結果, PAS 染色により腺癌, 杯細胞の粘液, 扁平上皮細胞のグリコ ーゲンが陽性になり，アルシャン青染色により腺癌，杯 細胞の粘液が陽性となった。 また CEA 染色を転移性腺 癌について行った結果陽性を示し，これらの特殊染色も 可能であった.

\section{DTT 集細胞法での肺癌細胞の検出率}

肺癌症例 50 例より得られた 100 件の喀痰を用いて DTT 集細胞法と直接塗抹法での癌細胞検出率を比較し た. DTT 集細胞法の癌細胞検出率は $65.0 \%$ で，直接塗 抹法 $43.0 \%$ に比べ， $22.0 \%$ 高率であった．細胞型別で は扁平上皮癌 $67.5 \%$, 腺癌 $61.4 \%$ で，直接塗抹法の扁 平上皮癌 $47.5 \%$, 腺癌 $34.1 \%$ を大きく上回った（表 2).

また，肺癌症例 50 例の喀痰を用い，DTT 集細胞法と サコマノ法での癌細胞検出率の比較では，いずれの方法 も陽性率 70\% であり差は認められなかった。

\section{IV. 考察}

近年，肺癌の急増の対策として，早期発見のために喀 㽷細胞診が肺癌検診にも取り入れられるようになった。 集団検診では，喀出新鮮痰による検查は種々の点から不 適当であり，蓄㽷法を用いて行う必要がある. 現在， Saccomanno 法が広く行われているが，さらに大きな集 団を扱うようになれば，より簡便な方法が必要となる.

DTT 集細胞法は粘液融解性の強い DTT 用いてい るので，攬汼のみで短期間で粘液が融解される. 粘液融 解後は上清を捨て，沈渣を塗抹するのみで標本を作成で きるので，標本作成過程は非常に簡易となった．Saccomanno 法4,8) では器具の取り扱いなど操作が繁雑な点が あり, 同時に多検体の処理には問題となろう. その点, DTT 集細胞法では一度に多検体の処理ができ, 塗抹ま で同一の容器を用いて行うので, 検体間の混入の危険性 がなくなった，粘液融解剤アセチルシステインを用いた 方法2,8)ではアセチルシステインの濃度が高い場合には 細胞の染色性に変化がみられることがあり,また低濃度 のアセチルシステイン6では粘液の融解に時間がかかる. 一方，DTT 集細胞法は約 72 時間で $90 \%$ 以上の検体で 粘液が融解され，難溶性を示した検体もDTT 液を入れ 替えることにより粘液融解が可能で，短期間で標本作成 ができる．また同時に開発した粘液粉砕翼付の喀痰容器 は郵便ポストに投函可能で，郵送による検体の回収を可
表 2 DTT 集細胞法と直接塗抹法との喀痰細胞診成績の比較

\begin{tabular}{|c|c|c|c|}
\hline 細胞型 & $\begin{array}{l}\text { DTT 集細胞法 } \\
\text { 陽 性 例 }\end{array}$ & $\begin{array}{l}\text { 直接塗抹法 } \\
\text { 陽 性 例 }\end{array}$ & 検体数 \\
\hline 扁平上皮癌 & $27(67.5 \%)$ & $19(47.5 \%)$ & 40 \\
\hline 癌 & $27(61.4 \%)$ & $15(34.1 \%)$ & 44 \\
\hline 小細胞癌 & $7(70.0 \%)$ & $6(60.0 \%)$ & 10 \\
\hline その他の癌 & $4(66.7 \%)$ & $3(50.0 \%)$ & 6 \\
\hline 全 肺 癌 & $65(65.0 \%)$ & $43(43.0 \%)$ & 100 \\
\hline
\end{tabular}

（）内は陽性率

能にした．郵送による喀痰の回収は，回収率の向上にも つながると同時に検体回収時にすでに粘液が融解されて いるのでただちに標本作成に移ることができた。

DTT 集細胞法による標本では，背景に粘液片はなく 細胞は重層することなく均等に分布するため，スクリー ニングが容易であった. 細胞の保存状態は良く, 癌細胞, 非癌細胞の細胞所見は直接塗抹法に類似し，また，標本 中の癌細胞の出現数も多く, かつ癌細胞は細胞集団とし て出現する傾向にあるのでスクリーニングに際して発見 されやすいと思われる，扁平上皮癌細胞は小集団あるい は単個で出現し, 細胞質の染色性は良く, ときに細胞壊 死物質む小集塊として認められた。腺癌細胞は，重積性 または腺様配列を示す細胞集団として出現し, 細胞質は 泡沫状を呈した。 小細胞癌細胞は結合疎な集団または, 球状集団として出現し，核クロマチンは細顆粒状を呈し た. したがって, 細胞型の判定にあたっては従来の癌細 胞判定基準により判定可能であると考える.

また DTT 液のエタノールの濃度の検討を行ったとこ ろ, $25 \%$ 以下では細胞の膨化，染色性の低下が著明であ り，55〜65\% では，細胞の収縮と細胞全体の濃染傾向が 著しく細胞型の判定困難をきたす場合もあった。 また 70 $\%$ 以上のエノールでは, 喀痰が凝固し融解不能となっ た. 30〜 50\%に拉いては細胞の保存性，染色性とも良好 であったが， $30 \%$ エタノールでは，1 カ月間放置後，核 の染色性の低下と一部にクロマチンの無構造化が認めら れた。 また $50 \%$ エタノールでは, 粘液融解性の軽度低下 がみられた．以上のごとく $35 \sim 45 \%$ エタノールを使用 することによって，粘液の融解性が向上するとともに核 の濃染傾向, 細胞質の重厚化が軽減され細胞の微細構造 を保存することができた.さらに PAS 染色, アルシャ ン青染色，CEA（酵素抗体法）染色などの特殊染色が陽 性を示すことから DTT 液は細胞内物質には影響を与え ず機能的な面も保存できると考える.

DTT 液中に喀痰を 1 年間室温で放置し細胞形態の観 察を行ったが, 3 カ月までは特に変化はなかった. 1 年後 
でも, 腺癌細胞の細胞質に空胞化が目立ってきた点を除 けば大きな変化は認められず保存状態は良好であった。 また DTT 液を調整後 1 年間室温で保存したものでも粘 液の融解率は $92 \%$ で, 長期にわたって使用可能であっ た.

肺癌症例 50 例の喀痰を 2 等分し, 一方を Saccomanno 法, 一方を DTT 集細胞法を行い, 両者の肺癌細胞検出 率を比較検討したが，いずれの方法も陽性率 70\%であ り差は認められなかった.

肺癌症例の直接塗抹標本を作成した残 余の喀痰で DTT 集細胞法を行い癌細胞の検出率の比較をしたとこ ろ, DTT 集細胞法が $22 \%$ 高率であった. 特に腺癌での 陽性率の向上が著しかった. これはアセチルシステイン 集細胞法 ${ }^{2,8)}$, Saccomanno 法3)などでも報告されたと同 様の成績で, 集細胞法の効果と考えられる. 直接塗抹法 では，喀疢の一部しか塗抹されないため，標本中に癌細 胞が出現しないこと，あるいは癌細胞の出現が小数のた め診断が困難な場合があるそそれに比べ集細胞法では， 全喀痰からできるだけ多くの細胞を集めてくることによ り癌細胞が十分検出し得たのであろう ${ }^{6)}$. また標本作成 に当たっては直接塗抹法では，ある程度の熟練が必要で あり個人差が生ずることも陽性率に影響すると考えられ るが, DTT 集細胞法では沈渣を塗抹するだけなので誰 もが均一な標本を作成することができると考える.

DTT 集細胞法は, 標本作成が簡便で, 多数の検体を同 時に処理でき, また郵送が可能な点から, 増加の傾向に ある喀痰細胞診において有用な方法であると考える.

\section{Summary}

A new technique for collecting cells from sputum using Dithiothreitol (DTT) and a container of sputum specimen were developed. The container is convenient for posting in size and has webs for solving mucus. In the sputum smear sample by this method, mucus is completely dissolved and cells are distributed uniformly on the slide and cell clusters maintain their feature well. The stainability of cytoplasm and nucleus of cancer cells was almost the same as that of the direct smear method. The rate of positive cytologic diagnosis of the samples from pulmonary carcinoma patients was $65 \%$ by this method, $22 \%$ higher than that by direct smear method using the same sputum. The procedure of this method is simple, requiring only centrifugation but no other apecial apparatus. As many specimens can be handled at once, it is useful for preparing sputum specimens in mass survey.

\section{文献}

1) Bonime, R.G. : Improved procedure for the preparation of pulmonary cytology smears, Acta Cytol., $16: 543 \sim$ 545, 1972.

2) Horai, T. and Ueki, A. : The cell concentration Method Using Acethylcysteine for Sputum Cytology, Acta Cytol., $22: 580 \sim 583,1978$.

3）成瀬靖悦, 松田 実: Sacoomanno 法による喀痰細胞診成 績, 日臨細胞誌, $16: 195 \sim 204,1977$.

4) Pharr, S.L. and Faber, S.M. : Cellular concentration of sputum and bronchial aspiration by trypic digestion, Acta Cytol., $16: 447 \sim 454,1962$.

5) Saccomanno, G., Sunders, R.P., Ellis, H., et al. : Concentration of carcinoma or atypical cells in sputum, Acta Cytol., $7: 305 \sim 310,1963$.

6）佐藤博俊, 斉藤泰紀, 橋本邦久 : 早期肺癌カラーアトラス, 金原出版, 東京, 1985.

7) Takahashi, M. and Uebe, M. : A new cell concentration method for cancer cytology of sputum, Cancer, 16 : 199 204, 1973.

8）植木明美, 宝来 威: アセチルシステインによる喀痰集細 胞法, 日臨細胞誌, $16: 61 \sim 65,1977$. 